\title{
FACTORS AFFECTING SUSTAINABILITY OF WETLAND AGRICULTURE WITHIN LAKE VICTORIA BASIN IN UGANDA
}

\section{C. KYARISIIMA, I. NALUKENGE, W. KARIUKI AND S. MESAKI}

\begin{abstract}
In recent years, the high rate of conversion of wetlands for agriculture has raised environmental concerns in Uganda. A study was therefore conducted to identify issues that need to be addressed if communities are to continue deriving livelihoods from wetland agriculture, without causing stress to the wetlands of Lake Victoria basin. This was done by conducting household surveys and focus group discussions in two of the districts that border Lake Victoria. Wetland agriculture was found to be a significant source of livelihoods for resource poor communities, contributing over $60 \%$ of the household income. Farming was mainly done at a subsistence level. The study found that socio economic factors, poor farming practices and weak policies were contributing to the rapid conversion of wetlands. Concerted efforts need to be made by government institutions to sensitize communities on conservation of wetlands. Some of the policies need to be harmonized to avoid contradictions. Alternative sources of livelihoods must be created to ensure socio economic benefits and environmental conservation.
\end{abstract}

\section{Key words: Wetland agriculture; Sustainability; Livelihoods; Uganda.}

\section{INTRODUCTION}

The wetlands in Lake Victoria basin cover an extensive area and support a wide range of economic activities that sustain a significant proportion of communities within the East African region. In Uganda, the Wetlands Sector Strategic Plan (2001 - 2010) of the Ministry of water, Lands and Environment supports the concept of wise use of wetlands, in accordance with the Ramsar Convention. Ramsar Convention's definition of wise use of wetlands states that "wise use of wetlands is the maintenance of their ecological character, achieved through the implementation of ecosystem approaches, within the context of sustainable development" (Ramsar Convention Secretariat, 2007a). Thus, there is a recognition that some economic activities are inevitable but must be carried out in a sustainable way. Institutions that are charged with the responsibility of watching over wetlands exist at both national and local government levels but they are facing a lot of challenges in enforcing wise use of wetlands.

In the past, wetland agriculture was in response to anticipated food shortage, and was therefore one way of ensuring food security to rural communities. It was an important part of livelihood and a risk aversion strategy which did not involve conversion of whole wetlands. However, in recent years, wetlands have increasingly become attractive for cultivation and livestock rearing especially in the districts bordering Lake Victoria. The complete drainage and cultivation of wetlands is becoming a common phenomenon in many of the wetlands of Lake Victoria basin. Sustainability of the current farming activities in terms of sustainable livelihoods and wetland ecosystem functions has therefore become a great concern. A study was conducted to identify issues that would need to be addressed if communities were to continue deriving livelihoods from wetland agriculture, without causing much stress to the ecosystem. This involved an examination of socio economic characteristics of the farming communities, ecological factors, farming practices as well as governance issues.

\section{METHODOLOGY}

The study was conducted in two of the districts which border Lake Victoria, namely Wakiso and Masaka. The two study sites were selected, basing on the observable threat of farming activities on 
the wetland ecosystem. Wakiso has a peri-urban setting while the Masaka is rural. The main groups consulted included farmers, extension personnel and district agricultural and environment officers. In each of the study sites, purposive sampling was used to select four parishes and subsequently three villages in each parish where wetlands were being utilized for farming. With the help of village leaders, lists of households that farm in wetlands were compiled. Ten households were randomly selected from each village, making a sample of 120 households per study site. The selected households were interviewed, with the aid of a structured questionnaire. A total of two hundred and forty respondents were interviewed, but during data coding and entry some questionnaires were discarded due to gross errors that were found therein, leaving 109 and 108 respondents for Masaka and Wakiso, respectively. The questions were designed to gain information about the historical use of the wetlands in the area; changes in wetland use; reasons for the changes in wetland use; ownership and usage issues; policy issues and farmers' perception of the importance of wetlands. Key stakeholders' workshops and focus group discussions were also held, to allow community participation in open discussions as a means of exploring wetland management issues. Resource management problems and priorities were identified through ranking and scoring methods. The data were analyzed using descriptive statistics generated by Statistical Package for Social Sciences (SPSS). Relationships between socio economic and demographic characteristics in relation to the extent of conversion of the wetlands resource were examined using linear regression analysis.

\section{RESULTS AND DISCUSSION}

Local communities, in their local dialects, have characterized the wetlands basing on the type of dominating vegetation, soils and water levels. Some wetlands are therefore perceived as being suitable for agriculture while others may not be approached at all because of their ecological nature. Wetland inventories are lacking at the village level in all areas. The proportion of the wetland converted for agriculture ranged from as low as $10 \%$ up to well over $80 \%$. Residents in the area confirmed that wetland conditions relating to water quantity and quality, soils, vegetation and function had worsened over time, causing changes in weather and a decline in crop yields. This therefore is contrary to Ramsar's definition of wise use of wetlands which emphasizes high yields and continuous benefits while maintaining the wetlands' potential to meet the needs and aspirations of future generations (Ramsar Convention Secretariat, 2007a). According to Sullivan (2003), sustainable farming involves growing crops and livestock in ways that simultaneously address environmental conservation, profitability, and social benefits for the farm family and the community as a whole, while according to the Uganda National Wetlands Programme (1994), wetland abuse refers to any action in wetlands that leads to loss or reduction of the hydrological and ecological functions. On the other hand, denial of access would deprive communities of useful wetland resources and could therefore be termed as abuse of peoples' rights. This calls for strategies that can achieve a win-win situation. The measures of sustainability of a farming system ought to be more than a set of idealistic principles or practices (ShaoXiang, 2003). A variety of indicators must be used to assess whether or not a farming community is achieving the three objectives of sustainability. Such indicators may be based on socio economic characteristics of the farming communities, ecological factors, agronomical practices as well as governance issues.

Wetlands in Wakiso and Masaka district are a victim of large populations in households. Household size of people who farm in wetlands ranged from 1 up to 19 persons. On average, households of people who farm in wetlands in Wakiso are located within 300 metres from the wetlands. Similarly, $46.2 \%$ of the respondents in Masaka live within less than 100 metres of wetlands, while another 25\% reside 100-300 metres from the wetlands. However, in both sites some farmers came as far as five kilometers away. This shows the importance of sensitizing whole communities rather than concentrating on villages where wetlands are located. Household size 
coupled with close proximity of the households may have a significant impact on sustainability of the wetlands ecosystem. The impact of household activities creates unsustainable conditions for wetland conservation.

About $40 \%$ of the population farming in Wakiso wetlands attained primary school education, while 3.8\% never went to school at all (Table 1). In Masaka, $12.5 \%$ had no formal education and $62.5 \%$ of the respondents had primary level education as the highest level. The difference here is probably because of Masaka being a rural area. The level of education attained by local wetland users is therefore generally low. This could have a negative impact on the implementation of wetland conservation measures since it influences the level of awareness of policies and other legal frameworks under which wetland conservation operates.

Table 1. Level of education of respondent household heads in Wakiso and Masaka

\begin{tabular}{|l|l|l|l|l|}
\hline \multirow{2}{*}{ Site } & \multicolumn{4}{|c|}{ Level of education } \\
\cline { 2 - 5 } & None & Primary & Secondary & Tertiary \\
\hline Wakiso & $3.8 \%$ & $39.1 \%$ & $40.0 \%$ & $17.1 \%$ \\
\hline Masaka & $12.5 \%$ & $62.5 \%$ & $20.2 \%$ & $4.8 \%$ \\
\hline
\end{tabular}

According to Nyeiteera (1998) people with high knowledge scores are more likely to support regulations put in place for the conservation of the environment. In Uganda, much of the information written in manuals and other policy documents which is normally presented in English may not easily be understood by the majority of the users. In addition, even if they were translated into local dialects, there is so far no reading culture in Uganda.

The majority heads of households in the survey were below 40 years of age and have not lived in the area for more than 15 years, implying that there has been a lot of migration into the wetland areas resulting from increased population pressure on land as well as urbanization. Many of the youths aged below 35 in both study sites were mainly engaged in commercial vegetable farming rather than food production for the home. Age of household heads could have implications in terms of experience and perhaps wisdom. Older people tended to recall the benefits of intact natural resources and felt sorry about the degradation of the wetland resources, while youths seemed to "live for today and cared less for tomorrow". Many of the youths were renting the wetland plots and therefore tried to maximize utilization of the land before landlords could stop them. This kind of farming practice is not sustainable and can easily lead to the destruction of the wetlands.

Farming featured strongly as the major occupation of the surveyed households, contributing over $60 \%$ to household incomes. In Masaka, $84.4 \%$ of the respondents stated that farming was their primary occupation (Table 2), out of which $53.3 \%$ had farming as the only source of livelihood. In Wakiso $47.7 \%$ of the respondents had farming as the primary occupation, while $42.6 \%$ of the households cited farming as the main secondary economic activity. Most of the later were involved in clay mining and brick making as their primary occupation which is equally a threat to the wetland ecosystem.

Table 2. Primary occupation of respondent household heads in Wakiso and Masaka

\begin{tabular}{|l|l|l|l|l|l|}
\hline & Farming & $\begin{array}{l}\text { Sand/clay } \\
\text { mining }\end{array}$ & Trade & Civil service & Others \\
\hline Wakiso & $47.7 \%$ & $22.9 \%$ & $13.3 \%$ & - & $16.1 \%$ \\
\hline Masaka & $84.4 \%$ & - & $5.5 \%$ & $4.8 \%$ & $5.3 \%$ \\
\hline
\end{tabular}




\section{$\underline{\text { Journal Of Agriculture and Social Research (JASR) Vol. 8, No.1, } 2008}$}

It was noted that another category of people who farm in wetlands are the wealthy people who have drained some wetlands for dairy farming or established greenhouse floriculture farms in the wetlands. These responses indicate the gravity of farming activities on wetlands, making them highly vulnerable because wetland uses determine the extent of sustainability of the wetland ecosystems.

Many of the respondents claimed ownership of the wetland farm plots, some having up to six gardens/plots in the wetlands, yet according to the Uganda Constitution (1995), wetlands are supposed to be public land. Total garden size ranged from 0.08 hectares up to about 1.6 hectares, with the majority $(>55 \%)$ having about 0.4 hectares in scattered plots. Details of the mode of acquisition of the plots are shown in Table 3. Some households claimed to have farmed in the wetlands for up to 40 years, but the majority claimed to have occupied the wetland farm plots for 11-20 years. Degradation of wetlands often results from weaknesses in legal frameworks for land tenure and resource use (Ramsar Convention Secretariat, 2007b). 
Table 3. Ownership of wetland farm plots

\begin{tabular}{|c|c|c|c|c|c|c|}
\hline \multirow[t]{2}{*}{ Site } & \multirow{2}{*}{$\begin{array}{l}\text { Ownership } \\
\text { claims }\end{array}$} & \multirow{2}{*}{$\begin{array}{l}\text { No. of } \\
\text { plots }\end{array}$} & \multirow{2}{*}{$\begin{array}{l}\text { Possession } \\
\text { of tenancy } \\
\text { documents }\end{array}$} & \multicolumn{3}{|c|}{ Mode of acquisition } \\
\hline & & & & Inherited & Purchased & $\begin{array}{l}\text { Rented or } \\
\text { borrowed }\end{array}$ \\
\hline Wakiso & $42.1 \%$ & $1-6$ & $32.4 \%$ & $39.1 \%$ & $36.5 \%$ & $24.4 \%$ \\
\hline Masaka & $72.4 \%$ & $1-6$ & $43.2 \%$ & $34.4 \%$ & $48.1 \%$ & $17.5 \%$ \\
\hline
\end{tabular}

Although Uganda government policy stipulates that wetlands are "held in trust" by the government for the good of all citizens of Uganda (The Uganda Constitution, 1995) many people still claim individual ownership of wetlands adjacent to their properties. Older people, however, clarified that in the past (before 1960s), wetlands were not included on the land titles of surveyed land. The problem of claiming ownership of wetlands came up over the years when there was a breakdown in government institutions due to political instability. As suggested by Gawler (1998), political stability and security are very important in sustainability of ecosystem health. Civil servants in the two districts confirmed that despite the existing government policy, conflicts and contradictions concerning ownership of wetlands still do exist. Stakeholders further observed that the definition of public ownership of wetlands may not be as clear as expected, making management of wetlands difficult. Ownership by government, which may in some cases imply communal ownership, tends to encourage haphazard utilization of wetlands, because nobody is held responsible for proper management of the wetlands under communal ownership. Individuals who have access to the wetlands tend go for short-term gains, satisfying their immediate (short-term) livelihood demands. Thus the concept of government ownership of wetlands also tends to encourage an "I don't care attitude". On the other hand, ownership claims imply that a land owner has the right to use his property the way he wants and the local village leadership has no control over his activities. The Land Act (1998) provides for the formation of communal wetlands associations for the management of wetlands, but this has not been put into practice. If these existed, their implementation would help in regulating farming activities that are carried out in wetlands. Co-management of natural resources has been suggested as an important tool for conflict management and even resolution since it encourages dialogue and transparency (Gawler, 1998).

The closer the households were to the wetlands, the more the proportion of the wetland was converted for agriculture. This was true for both study sites, as indicated in Tables 4 and 5 . In Masaka, age of household head was found to have a significant negative relationship with the percentage of the wetland converted for farming. The amount of wetland converted for farming was significantly related to ownership claims in Masaka where over $70 \%$ of respondents claimed ownership of wetland farm plots. By law, wetlands are public land and nobody ought to claim their ownership (The Uganda Constitution, 1995), thus weaknesses in law enforcement are among the causes of the increasing rate of encroachment on wetlands. 
Journal Of Agriculture and Social Research (JASR) Vol. 8, No.1, 2008

Table 4. Factors influencing the extent of conversion of wetlands for agriculture in Wakiso

Dependent variable $=\%$ of wetland converted for agriculture

Explanatory variables Coefficients t-value

\begin{tabular}{lll}
\hline Constant & 65.164 & 2.380 \\
Location of farm household & -0.606 & $-2.272^{*}$ \\
Age of household head & -0.064 & -0.283 \\
Household size & 0.268 & 1.331 \\
Level of education of household head & 0.397 & 1.617 \\
Claim of ownership of wetland & 0.145 & 0.811 \\
$\mathrm{R}^{2}$ & 0.744 & \\
\hline
\end{tabular}

* Significant at $<0.05$ level

Table 5. Factors influencing the extent of conversion of wetlands for agriculture in Masaka

Dependent variable $=\%$ of wetland converted for agriculture

Explanatory variables Coefficients t-value

Constant $\quad 69.049 \quad 4.571$

Location of farm household $\quad-0.276 \quad-2.729 * *$

Age of household head $\quad-0.258 \quad-2.108^{*}$

$\begin{array}{lll}\text { Household size } & -0.100 & -0.830\end{array}$

Level of education of household head $\quad-0.053 \quad-0.468$

Claim of ownership of wetland $0.209 \quad 0.976^{*}$

$\mathrm{R}^{2} \quad 0.272$

* Significant at $<0.05$ level; ** Significant at $<0.01$ level

Respondents presented three main reasons for encroaching on wetland resources for farming (Table 6). Whereas land shortage was the main reason given by Wakiso farmers, those in Masaka were looking for a reliable source of water for all-year-round farming. Surprisingly, loss of soil fertility in the upland areas which appears to be a serious challenge in Masaka was not perceived as a big problem by the respondents. The differing reasons for farming in wetlands could be attributed to location of the study sites. Wakiso, being a peri-urban setting, is faced with a rapid increase in population, having an annual population growth of more than 4\%, (Wakiso District Environment Action Plan, 2006), hence it is not surprising that shortage of farming land is the main reason for encroaching on wetlands.

The main farming activities in Wakiso were sugarcane and vegetable growing (Table 7). The two crops were primarily grown as cash crops. The main crops grown in the wetlands of Masaka district were sweet potatoes, yams and maize, implying that the farmers' main concern was first and foremost to produce food for the home. Hardly anyone applied artificial fertilizers. 
Journal Of Agriculture and Social Research (JASR) Vol. 8, No.1, 2008

Table 6. Reasons given by respondents for farming in wetlands

\begin{tabular}{|l|l|l|}
\hline & Wakiso & Masaka \\
\hline Land shortage/no other land & $69.2 \%$ & $26.2 \%$ \\
\hline Poor upland soils/search for fertile soils & $20.2 \%$ & $11.7 \%$ \\
\hline Reliable water source for all-year-round farming & $10.6 \%$ & $62.1 \%$ \\
\hline
\end{tabular}

Only vegetable growers used farm yard manure to replenish soil fertility. Pesticides and fungicides were used by only vegetable growers. Maize and beans are among crops which are not water tolerant. Cultivation of such crops in Masaka wetlands could serve as a clear indication of wetland degradation. Cultivation of such crops would involve excessive drainage so as to lower the water table to a level that will prevent water logging in the crop root zone (Dixon and Wood, 2003).

Table 7. Farming activities in the wetlands of Wakiso and Masaka

\begin{tabular}{|l|l|l|l|l|l|l|l|l|}
\hline & $\begin{array}{l}\text { Sugar } \\
\text { cane }\end{array}$ & $\begin{array}{l}\text { Yams } \\
\text { \& sweet } \\
\text { potatoes }\end{array}$ & Vegetables & Maize & Beans & $\begin{array}{l}\text { Dairy } \\
\text { farming }\end{array}$ & $\begin{array}{l}\text { Fish } \\
\text { farming }\end{array}$ & Others \\
\hline Wakiso & $32 \%$ & $10 \%$ & $21 \%$ & - & - & $6 \%$ & $9 \%$ & $22 \%$ \\
\hline Masaka & $7 \%$ & $38 \%$ & $16 \%$ & $25 \%$ & $9 \%$ & - & - & $5 \%$ \\
\hline
\end{tabular}

Excessive drainage impacts on the general hydrological functions of wetlands. The methods used for land clearing in both study sites included bush burning and construction of deep drainage trenches. The few cattle and goats that were reared by the resource poor farmers were either tethered or communally grazed in wetland edges. Farmers highlighted seasonal floods as the major problem faced when farming in wetlands. Construction of deep drainage trenches was their main coping strategy. Other problems mentioned included pests and diseases, theft and occasional harassment by National Environment Management Authority (NEMA) officials. Over 80\% of the respondents were aware that farming in wetlands lowers the water table and water quality, but this did not bother them, indicating that they probably did not care much for the future of the wetland ecosystem.

The values of wetlands appeared to be perceived in various ways, which included moderation of climate, farming and water storage (Figure 1). The respondents who cited moderation of climate and water storage agreed that Uganda would be drought stricken if all wetlands were destroyed. It was interesting to note that a considerable proportion of respondents in both sites named farming among the perceived values of wetlands. 


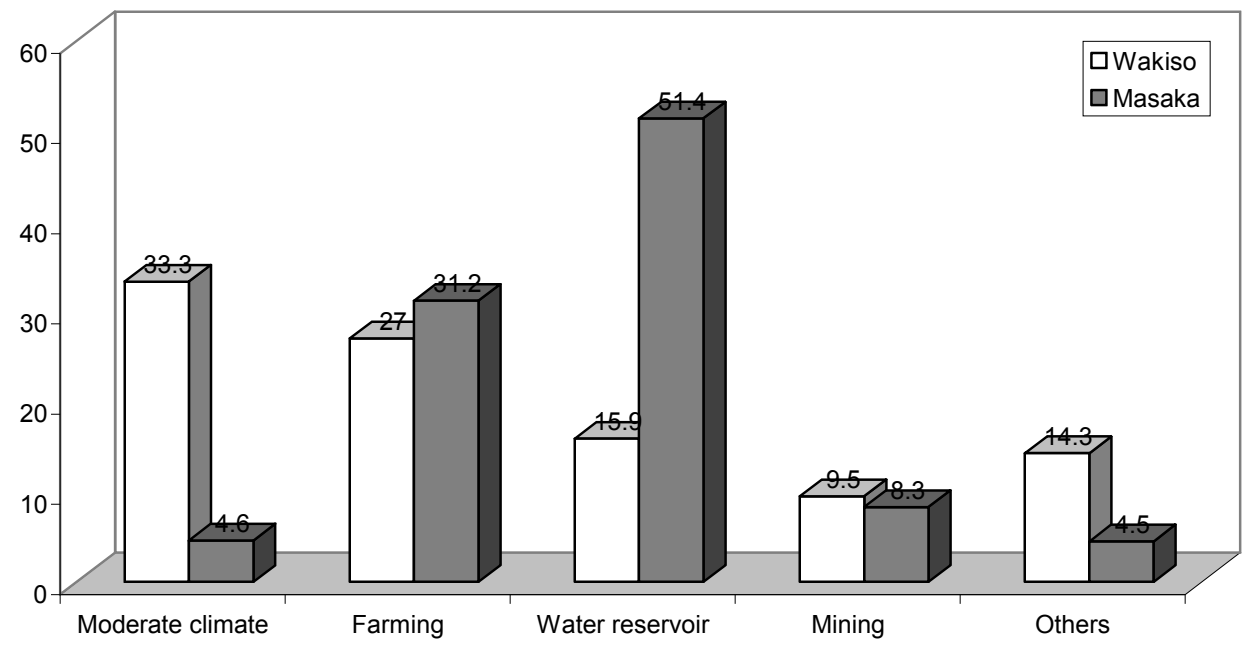

Figure 1. Perceived values of wetlands

When asked what they considered to be serious threats to wetlands, most of the respondents in Wakiso said they did not know; while others named brick making, human settlements, and overharvesting of wetland vegetation as the main threats (Figure 2). However the trend was different for Masaka respondents who admitted that farming in wetlands was the main threat to wetland conservation. When asked what they considered to be wetland abuse, $45 \%$ of the respondents in Masaka named excessive drainage of water and sand mining while those in Wakiso $(83.5 \%)$ named clay mining. In Wakiso, as long as farming in wetlands was done at a subsistence level, farmers did not perceive it as an abuse. This was an indication of the conflicts that exist between the indigenous people and the wealthy investors. Gawler (1998) similarly observed that threats to wetlands often involve issues of equity amongst stakeholders.

The deferring perception of wetland values by communities in the present study is an indication that communities are not homogeneous in terms of socio economic characteristics. It implies that wetlands have stakeholders who have different sets of interests, needs, rights and influence and such issues must be central to the development of sustainable wetland management (Wood, 2003). It is therefore not surprising that in Wakiso, conversion of wetlands for farming was not considered to be a serious threat to wetland conservation, although up to $60 \%$ of some wetlands have been cleared for farming. Nyeiteera (1998), after getting a similar response concluded that massive degradation of some wetlands in this area was mainly based on greed. The indifference exhibited by wetland users in Wakiso could probably be attributed to the fear of being evicted from the wetlands because many of them could only accept to be interviewed after ascertaining that the research team was not associated with NEMA. 


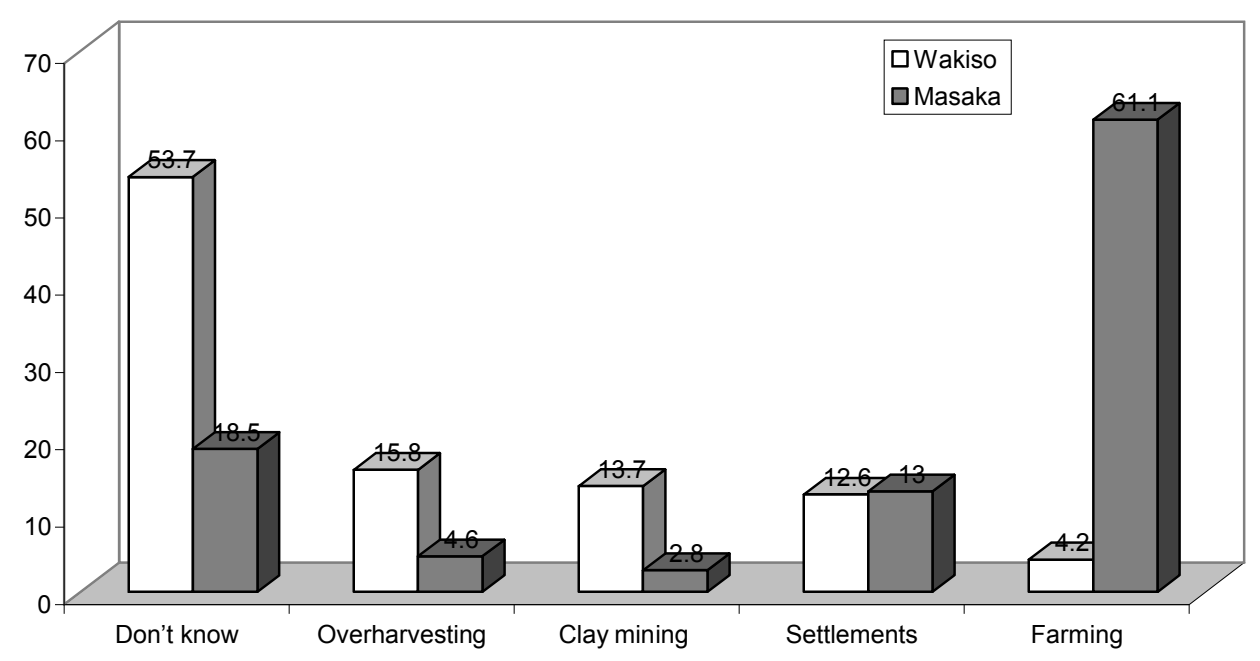

Figure 2. Perceived threats to wetlands

While working in Ethiopia, Dixon and Wood (2003) similarly observed that rural households who utilize wetland resources for a livelihood find it difficult to see beyond the immediate and shortterm results and to recognize the long term degradation threats. However the trend was different for Masaka respondents who admitted that farming in wetlands was the main threat to wetland conservation. In fact Masaka communities showed a desire to be taught how to use the wetland resources sustainably instead of being evicted.

The survey findings indicated that the majority $(>60 \%)$ of the respondents were aware that government policy advocates for the conservation of wetland resources. However, they were not sure of the specific rules governing the utilization of wetlands. The respondents cited clay and sand mining, house construction and burning of wetlands as illegal. Over $70 \%$ of the respondents said they got the information about government policy through radio. Other sources of information mentioned included neighbours, newspapers and local extension officials. Although institutions that are charged with the responsibility of watching over wetlands exist at both national and local government levels, effective conservation of wetlands remains a challenge. Some of the problems are attributed to weak policies. For instance, the roles of the Local Environment Committees are not clear. These committees are not even equipped with information and means of overseeing the environment. Stakeholders pointed out that there are weaknesses within the Local Government Act of 1997 which would need to be revised so as to empower the existing institutions. For instance, local leaders are elected by communities and are therefore not capable of enforcing the laws for fear of conflicting with their electorate. In the past, local leaders were appointed as civil servants and would not necessarily work in their home villages. They had the powers and means of enforcing government laws.

Generally, communities appeared to be aware of the importance of wetlands and their multiple functions but they are driven into over exploitation of the resource by the desire to earn a livelihood. In order to ensure sustainability of farming activities without degrading the wetlands, there is a need to explore more appropriate cropping regimes that are fairly compatible with the wetland conditions and are less destructive. This would require involvement of local communities in identifying such cropping systems as well as formulating relevant bye-laws. Kasoma (2003) suggested that management interventions need to be developed at the community level where wetlands are most impacted. Thus, institutional development at the wetland community level is 
paramount. Such an arrangement must have political support. Dixon and Wood (2003) suggested that awareness raising should first and foremost target policy makers within all sectors which share interests in wetlands conservation issues. In Uganda, this would call for collective effort across ministries that deal with agriculture, water, lands, environment, and local government. Dixon and Wood (2003) further suggested that when there is conflict between government policies and socio economic inequalities that lead to degradation of natural resources, there is need not only to focus on creation of awareness but also to test technologies, develop institutions and allow policy analysis and reform.

\section{CONCLUSIONS AND RECOMMENDATIONS}

Socio economic factors, poor farming practices and weak policies are all responsible for the rapid conversion of the wetlands in Lake Victoria basin. Unless efforts are put in place to ensure wise use of wetlands, the current farming practices are not sustainable. Haphazard utilization of wetlands for farming is bound to result in serious environmental problems in the region. To achieve sustainable agriculture in a fragile ecosystem such as a wetland, long-term solutions to problems must be sought. For instance, it requires development of management practices that minimize the alteration of the hydrological function of the ecosystem. The ability to evaluate and replan is vital at the national level, as well as at the farming community level. There is need to involve communities in the establishment of indices and standards for the evaluation of the ecosystems. This should be preceded by aggressive awareness campaigns, using the various mass media available. When communities are well sensitized about the importance of wetland conservation, they are likely to participate in guarding against destruction of the ecosystem. Policies must be harmonized to avoid contradictions, and law enforcement ought to be strengthened. In addition, avenues for alternative sources of livelihoods must be created to ensure socio economic benefits and environmental conservation.

Acknowledgement

This research was financed by the Inter-University Council for East Africa, through Lake Victoria Research Initiatives (VicRes), a project which is funded by the Department for Research Cooperation, within the Swedish International Development Agency (Sida/SAREC).

\section{REFERENCES}

Bakema, R. J. and Mafabi, P. (2003) Towards sustainable wetlands management: The Ugandan experience. In: Wetlands of Ethiopia; Eds: Y. B. Abebe and K. Geheb. Proceedings of a seminar on the resources and status of Ethiopia's wetlands.

Dixon, A. B. (2002) The hydrological impacts and sustainability of wetland drainage cultivation in Illubabor, Ethiopia. Land Degradation \& Development 13 (1), 17-31.

Dixon, A. B, and Wood A. P., 2003. Wetland cultivation and hydrological management in eastern Africa: matching community and hydrological needs through sustainable wetland use. Natural Resources Forum. 27 (2), 117-129.

Gawler, M. (1998) What are the best practices? Lessons in participatory management of inland and coastal wetlands. In: M. Gawler (Ed.), Strategies for wise use of wetlands: Best practices in participatory management. Proceedings of a workshop held at the $2^{\text {nd }}$ International Conference on Wetlands and Development, November 1998, Senegal.

Kasoma, P. (2003) Wetland Research in the Lake Victoria Basin, Uganda Part: Analysis and synthesis Report. The Inter-University Council for East Africa - Lake Victoria Research Initiative, Kampala, Uganda.

National Wetlands Programme (1994) WetNews Newsletter Vol. 1. Ministry of Natural Resources, Kampala, Uganda. 
Nyeiteera, G. M. (1998) Wetland usage and support of wetland policy in Wakiso sub county, Mpigi District. M.A Thesis, Makerere University, Uganda.

Ramsar Convention Secretariat (2007a) Wise Use of Wetlands: A Conceptual Framework for the wise use of wetlands. Ramsar handbooks for wise use of wetlands, $3^{\text {rd }}$ edition, vol. 1 . Ramsar Convention Secretariat, Gland, Switzerland.

Ramsar Convention Secretariat (2007b) Laws and Institutions: Reviewing laws and institutions to promote the conservation and wise use of wetlands. Ramsar handbooks for wise use of wetlands, $3^{\text {rd }}$ edition, vol. 3. Ramsar Convention Secretariat, Gland, Switzerland.

ShaoXiang, N., ShaoHua, T., and Fei, Z. (2003) Sustainable utilization of wetlands in Lixiahe region in North Jiangsu Province, China. Rural Eco-Environment, 19: 61-64.

Sullivan, P. (2003) Applying the Principles of Sustainable Farming: Fundamentals of Sustainable Agriculture-ATTRA Publication. $\quad$ http://attra.ncat.org/attra-pub/PDF/Transiton.pdf

The Land Act (1998) The Republic of Uganda.

The Local Government Act (1997) The Republic of Uganda.

The Constitution of the Republic of Uganda (1995) The Republic of Uganda

The Wetlands Sector Strategic Plan (2001 - 2010). Wetlands Inspection Division, Ministry of Water, Lands and Environment, Kampala, Uganda.

Wakiso District Environment Action Plan, 2006. Wakiso District Council. The Republic of Uganda.

Wood, A. P. (2003) Wetlands, gender and poverty: Some elements of the development of sustainable and equitable wetland management. In: Wetlands of Ethiopia; Eds. Y.B. Abebe and K. Geheb. Proceedings of a seminar on the resources and status of Ethiopia's wetlands. 